\section{Container Production of Prostrate Garden Chrysanthemums}

\author{
Neil O. Anderson ${ }^{1}$ and Esther Gesick ${ }^{2}$ \\ Department of Horticultural Science, University of Minnesota, 1970 Folwell \\ Avenue, St. Paul, MN 55108
}

Additional index words. horizontal growth, groundcover chrysanthemums, fast cropping, rhizomes, stolons, wave habit

\begin{abstract}
The prostrate plant habit may be an important new trait for the garden chrysanthemum [Dendranthema $\times$ grandiflora Tzvelv. (=Chrysanthemum $\times$ morifolium Ramatuelle)] market. Fifteen prostrate and non-prostrate genotypes were evaluated in production trials, using Regular and Fast Cropping systems. At flowering, the following traits were evaluated: days to flowering (first, $50 \%, \mathbf{1 0 0 \%}$ ), flowering duration, pot coverage, plant uniformity, and salability. Salability was measured with consumer evaluations. Genotypes differed significantly for days to first and $\mathbf{1 0 0 \%}$ flowering, flowering duration, plant height, plant width, and plant uniformity. Cropping systems were significantly different for days to first and 100\% flowering. 'Snowscape', a semi-prostrate day-neutral cultivar, was earlier than all other genotypes for days to first flower. It also had the longest flowering duration. 'Snowscape' would be the best genetic source for creating early, continual flowering cultivars. Most prostrate genotypes were as early as commercial cultivars. Genotype 90-275-27 was significantly shorter (prostrate) than all other genotypes and would be the best genetic source for prostrate plants. Genotypes 95-169-8, 92-237-9, 95-157-6, 95169-10, 90-275-27, and 'Snowscape' had the most acceptable plant width for shipping. Plant uniformity of 95-169-10 and 95-169-8 matched that of 'Debonair' and 'Spotlight', all of which were significantly more uniform than the other genotypes. The least uniform prostrate was 95-331-10. 'Snowscape' had the highest (best) index of traits ranking and was significantly better than all other genotypes. Consumer evaluations were highest for non-prostrate cultivars.
\end{abstract}

Garden chrysanthemums are interspecific hybrids derived from 10 or more species (Dowrick, 1953; Smith and Laurie, 1928). The current U.S. market size for garden chrysanthemums is $\$ 103.24$ million (wholesale) per year (U.S. Dept. of Agriculture, Statistics Board, 2002). Consumer flower color preferences in the fall crop market are yellow $(27 \%)$, lavender $(22 \%)$, bronze $(18 \%)$, white $(15 \%)$, red $(14 \%)$, and coral salmon $(4 \%)$. Decoratives (76\%) and daisies (22\%) are the two most popular flower types. Fall chrysanthemums remain an important crop for growers, as they involve a short growing season, a definitive peak selling time, no photoperiod manipulation, and relatively low production costs (Langevin, 1992).

The most significant production cost is labor, provided irrigation and a slow-release fertilizer regime is implemented. With Yoder's "Regular Cropping" (15-16 weeks), hand pinching occurs from one to four times during the growth phase until 20 July. Labor inputs increase significantly with each pinch, as the number of lateral breaks escalates. A

Received for publication 19 Sept. 2002. Accepted for publication 28 Jan. 2003. Scientific Journal Series Paper No. 021210109 of the Dept. of Horticultural Science. This research was funded by a grant from the Richard E. Widmer Research and Education fund and, in part, by the Minnesota Agricultural Experiment Station.

${ }^{1}$ Assistant Professor; to whom reprint requests should be addressed. E-mail address: ander044@ tc.umn.edu

${ }^{2}$ Research Fellow. commercial method to decrease labor and eliminate pinching is Yoder's "Fast Cropping" (9-10 weeks), although the final product is smaller and retails for less than plants from "regular cropping."

The Univ. of Minnesota garden chrysanthemum-breeding program has focused on product development for nearly 80 years. The release of $>70$ winter-hardy, early blooming mum varieties have provided the market with cultivars and germplasm critical for continued development by the private industry. Several Minnesota cultivars have remained popular on the market for many years, including 'Minngopher', PPNo. 4,327 (Widmer, 1978). Cultivars year (Univ. of Minnesota selection 90-275-27). in the 'Minn' series all possess a cushion plant habit, which revolutionized the industry and has the majority market share. The recent creation and release of large shrub-type chrysanthemums with the cushion habit from the university breeding program, sold under the brand My Favorite ${ }^{\mathrm{TM}}$, has created worldwide interest in new phenotypes.

Initial breeding objectives for garden chrysanthemums included early flowering and winter hardiness. To achieve this goal, many wild and/or cultivated chrysanthemum species were used (Longley, 1936, 1938; Morrison, 1923). The first garden chrysanthemum released by the program, 'Duluth', was an exceptionally winter-hardy type (Clark, 1962). The species used in the Univ. of Minnesota breeding program included the following: Dendranthema indicum, D. sibiricum, D. koreanum, D. arcticum, D. nipponicum, D. rubellum 'Clara Curtis', $D$. uliginosum, D. weyrichii, D. zawadskii, and Leucanthemum maximum (Longley, 1943, 1949, 1950; Teynor, 1990).

Another new plant habit-prostrate chrysanthemums - has been developed by the breeding program. Prostrate chrysanthemums have lateral branches, which grow horizontally along the soil surface in field and container trials (Fig. 1). The trait is genetically controlled, allowing for clonal propagation. Neither plant growth regulator applications nor mechanical manipulations are necessary to induce the horizontal growth. Thus, these prostrate chrysanthemums differ from the cascade chrysanthemums used in botanic gardens for fall flowering shows, whose cascading effect results from vertically downward growth by training and pinching (Alfors, 1977; Bruckhaus, 1975; Miller, 1976; ). Cascade chrysanthemums are grown as hanging plants in large containers, achieving lengths of 1.8 to $2.1 \mathrm{~m}$ at flowering. Prostrate chrysanthemums may be useful in hanging baskets, rock gardens, and large container plantings (Gesick, 1997). Given the increase in sales of petunias after the release of prostrate 'Wave' TM petunias, e.g., \$58.692 million sales in petunia (flats only) for 1994 vs. \$137.056 million (flats, potted, hanging baskets) for 2001 (U.S. Dept. of Agriculture, Statistics Board, 1995, 2002), a similar revo-

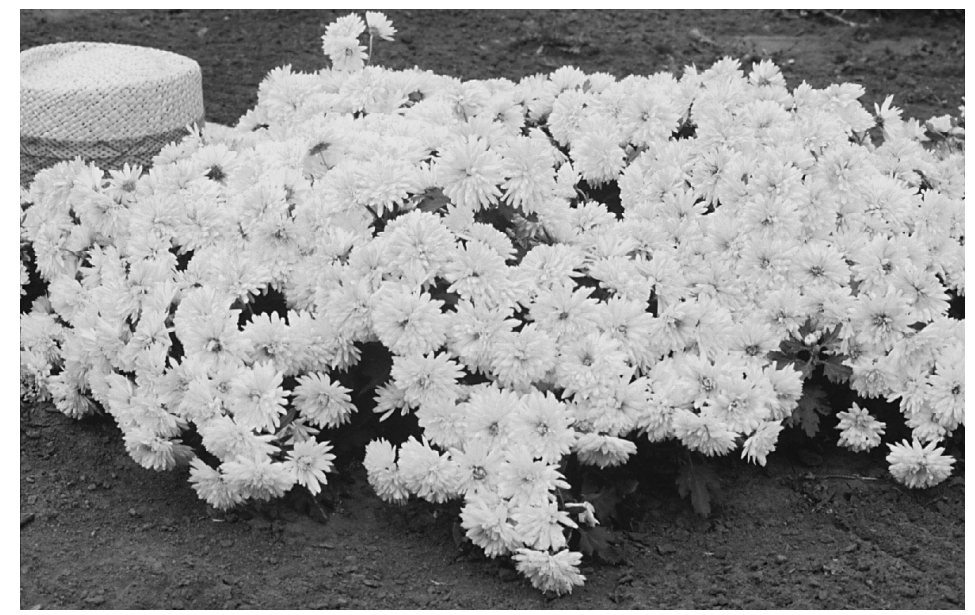

Fig. 1. Plant growth habit and flowering of a prostrate garden chrysanthemum selection during the first 
lution could occur in the garden mum market with prostrate or wave-type cultivars.

Most prostrate genotypes selected in the breeding program have at least one wild species in common in their pedigrees, either $D$. zawadskii or D. weyrichii (N.O. Anderson, unpublished data). Crosses in other breeding programs between early flowering garden types of $D . \times$ grandiflora with other wild species, $D$. vestitum, D. chanetii, D. lavandulifolium, D. indicum, also have produced similar phenotypes (Junyu et al., 1995). In the Univ. of Minnesota breeding program, most prostrate types trace to either 77-AM3 or 'Lindy' inbred families. Prostrate types have surfaced in the breeding program since its inception, although they were initially discarded since they did not match the desired ideotype. No previous reports of prostrate growth habit in other U.S. chrysanthemum trials or breeding program progenies have been reported (Butterfield, n.d.; Carpenter and Shackelford, 1966), although Chinese breeders have recently released small groundcover types (Junyu et al., 1995).

The prostrate phenotype is characterized by horizontal growth of the lateral branches that are attached to the plant at the crown. Field observations of numerous prostrate genotypes for $>12$ years have consistently shown that the lateral branches never root into the soil, despite the presence of nodes. Such aboveground, horizontal stems could be termed non-rooting stolons (Harris and Harris, 1994). Prostrate types follow the typical flower color, flower type, and short day response groups shared by all other commercial chrysanthemums. The cushion (hemispherical) chrysanthemum phenotype follows a plant height : width ratio of $1: 1$. In standard (upright) types used as cut flowers, height : width ratios are 1.5-2:1. Prostrate types possess $1: 3,1: 4$, or 1:6 height : width ratios. Prostrate types vary in their plant spread, from $0.3 \mathrm{~m}$ (Chinese types) to $0.9-1.5 \mathrm{~m}$ (U.S. types) in diameter.

The objective of this research was to evaluate the production of prostrate genotypes for fall chrysanthemum sales. Production trials for fall flowering consisted of Yoder's "Regular Cropping" and "Fast Cropping" systems with comparison cultivars to demonstrate production, growth habit differences, and consumer preferences.

\section{Materials and Methods}

Plantmaterial. Table 1 lists the garden chrysanthemums used in the experiment, including commercial cultivars and unnamed, numbered genotypes from the prostrate breeding program. Cultivars included the major flower color classes of yellow, lavender, bronze, white, and red.

Culture. Plants were grown outdoors under natural daylengths (long days to short days as the season progressed) at $45^{\circ} \mathrm{N}$ lat.; two rooted cuttings were planted $(20-\mathrm{cm}$ mum pans, spaced $45 \mathrm{~cm}$ O.C.) in early June 1999 (week 23), for the Regular Cropping schedule and in week 30 for the Fast Cropping program. They were grown outdoors until a killing freeze on 31 Oct. 1999 (week 44), which ended the experiment. Cultural conditions matched the recommendations of Langevin (1992) and Gesick (1997) for commercial container production except that no genotypes were pinched. The experiment was a split plot design, with the main plot consisting of the cropping systems $(n=2)$, the subplot of genotypes $(n=15)$, with replications $(n=3)$ constituting the blocks.

Data Collection. The following data was collected with the production experiment: days to flowering (first, $50 \%, 100 \%$ ), flowering duration (number of days from $50 \%$ flowering to senescence), pot coverage (plant height and width), plant uniformity (for flowering date, flower distribution, plant shape; a 1-5 scale, with $1=$ non-uniform, 5 = uniform), and salability (consumer evaluations) (Gesick, 1997). A modified index of traits (Gesick, 1997) was calculated and analyzed using a fixed effects one-way analysis of variance (ANOVA). All data analyses were conducted using Statistical Package for the Social Sciences (SPSS, version 10; SPSS Inc., Chicago). The relative performance of cultivars was assessed using mean comparisons.

Chrysanthemum breeders can use the index of traits to select genotypes with a coincident bloom time (Gesick, 1997). Traits included in the index (pot coverage - plant height and width, plant uniformity; earliness - days to first and $100 \%$ flowering, flowering duration) were either recorded on the date of $100 \%$ flowering or are expressed in relation to flowering. The highest, positive values for the index of traits

Table 1. Prostrate and non-prostrate garden chrysanthemum genotypes used in the production experiments.

\begin{tabular}{llll}
\hline Genotype & Color & Plant habit & \multicolumn{1}{c}{ Source } \\
\hline $90-275-27$ & yellow & prostrate & Univ. of Minnesota \\
$95-105-2$ & yellow & prostrate & Univ. of Minnesota \\
Jessica & yellow & non-prostrate & Yoder Brothers \\
$95-331-6$ & lavender & prostrate & Univ. of Minnesota \\
Snowscape & lavender & semi-prostrate & Univ. of Minnesota \\
Debonair & lavender & non-prostrate & Yoder Brothers \\
$95-169-10$ & bronze & prostrate & Univ. of Minnesota \\
$95-331-10$ & bronze & prostrate & Univ. of Minnesota \\
Jennifer & bronze & non-prostrate & Yoder Brothers \\
$95-157-6$ & white & prostrate & Univ. of Minnesota \\
$92-237-9$ & white & prostrate & Univ. of Minnesota \\
Spotlight & white & non-prostrate & Yoder Brothers \\
$95-169-8$ & red & prostrate & Univ. of Minnesota \\
95-160-49 & red & prostrate & Univ. of Minnesota \\
Helen & red & non-prostrate & Yoder Brothers \\
\hline
\end{tabular}

are desirable for selection purposes. The index of traits was calculated by first standardizing all data to Z-scores (Gesick, 1997; Montgomery, 1991), prior to summing the $z$-scores using the following equation: [-plant height + plant uniformity

- flowering earliness (or days to first flower)

+ flowering duration - days to $100 \%$ flowering]

Consumer evaluations were performed using a subsample of the production experiment, i.e., one prostrate and one non-prostrate cultivar from each of the flower color classes: yellow ('Jessica', 95-105-2), lavender ('Snowscape', 'Debonair'), bronze ('Jennifer', 95-169-10), white ('Spotlight', 92-237-9), and red ('Helen', 95-169-8). Inclusion of all genotypes would have been a deterrent to obtaining willing participants in the consumer evaluation. Evaluation of 10 plants was still enough to turn away potential evaluators, since it took $\approx 30$ min per evaluation.

Evaluations were performed in the Univ. of Minnesota, St. Paul, campus student center at the time of peak flowering (Sept. 1999). Twenty consumers who walked by the table (with the plants for evaluation) were randomly selected and invited to evaluate these prostrate and non-prostrate cultivars. Participants filled out a survey, rating each cultivar for flower color (on a 1-10 scale, with 10 being the best), flower form (1-10 scale), quality (1-10 scale), and overall appearance (1-10 scale), using a modified version of Gesick's (1997) standard form. Data from the surveys were analyzed using Friedman's two-way ANOVAby ranks and Kendall's rank correlation procedure. Multiple comparisons were performed using a 5\% LSD (Gesick, 1997). Each consumer's survey constituted a block in the experiment, while each genotype being evaluated served as a treatment. The null hypothesis being tested was $\mathrm{H}_{\mathrm{o}}$ : the consumer rankings are independent or random, versus the alternative hypothesis $\left(\mathrm{H}_{\mathrm{a}}\right)$ of $\mathrm{H}_{\mathrm{a}}$ : there is some order to the rankings.

\section{Results.}

Analysis of variance (ANOVA) showed no differences between replications of a cultivar for days to first flower, days to $100 \%$ flowering, and flowering duration (Table 2). In addition, no significant interactions were found for these traits. Genotype (cultivar) was highly significant for days to first flower and significant for days to $100 \%$ flowering and flower duration (Table 2). Cropping systems were highly significant for days to first and $100 \%$ flowering, but nonsignificant for flowering duration. Cropping systems and interactions (genotype $\times$ block, genotype $\times$ cropping system) were nonsignificant for plant height, plant width, and plant uniformity (Table 2). Replications were again nonsignificant, with the exception of plant height. Cultivars were highly significant for all three traits (Table 2). No significant interactions were found for any of the six traits (Table 2).
Index of Traits Number $=$ 
Table 2. Mean separations (Tukey's 5\% $\mathrm{HSD}^{2}$ ) and ANOVA for days to first flower, days to $100 \%$ flowering, flowering duration (50\% flowering to senescence), plant height/width, and plant uniformity of prostrate vs. non-prostrate garden chrysanthemums grown under two cropping systems.

\begin{tabular}{|c|c|c|c|c|c|c|}
\hline \multirow[b]{3}{*}{ Cultivar } & \multicolumn{2}{|c|}{ Days } & \multirow{3}{*}{$\begin{array}{c}\text { Flowering } \\
\text { duration } \\
\text { (days) }\end{array}$} & \multirow{2}{*}{\multicolumn{3}{|c|}{ Plant }} \\
\hline & \multirow{2}{*}{$\begin{array}{l}\text { To first } \\
\text { flower }\end{array}$} & \multirow{2}{*}{$\begin{array}{l}\text { To } 100 \% \\
\text { flowering }\end{array}$} & & & & \\
\hline & & & & $\mathrm{Ht}(\mathrm{cm})$ & Width $(\mathrm{cm})$ & Uniformity $^{y}$ \\
\hline $90-275-27$ & $84.5 \mathrm{~b}$ & $103.0 \mathrm{ab}$ & $25.7 \mathrm{a}$ & $27.8 \mathrm{a}$ & $44.0 \mathrm{a}-\mathrm{c}$ & $1.4 \mathrm{ab}$ \\
\hline $95-105-2$ & $87.2 \mathrm{~b}$ & $101.8 \mathrm{ab}$ & $24.7 \mathrm{a}$ & $30.0 \mathrm{a}-\mathrm{c}$ & $36.3 \mathrm{ab}$ & $2.6 \mathrm{a}-\mathrm{c}$ \\
\hline Jessica & $77.0 \mathrm{ab}$ & $95.7 \mathrm{ab}$ & $34.0 \mathrm{ab}$ & $37.3 \mathrm{~cd}$ & $38.3 \mathrm{ab}$ & $3.4 \mathrm{bc}$ \\
\hline $95-331-6$ & $78.0 \mathrm{~b}$ & $98.7 \mathrm{ab}$ & $30.0 \mathrm{a}$ & $28.7 \mathrm{ab}$ & $53.2 \mathrm{~cd}$ & $3.1 \mathrm{a}-\mathrm{c}$ \\
\hline Snowscape & $49.0 \mathrm{a}$ & $94.7 \mathrm{ab}$ & $53.3 \mathrm{~b}$ & $36.7 \mathrm{~cd}$ & $42.3 \mathrm{a}-\mathrm{c}$ & $3.3 \mathrm{bc}$ \\
\hline Debonair & $72.8 \mathrm{ab}$ & $96.8 \mathrm{ab}$ & $31.3 \mathrm{ab}$ & $36.0 \mathrm{~b}-\mathrm{d}$ & $33.8 \mathrm{a}$ & $3.9 \mathrm{c}$ \\
\hline $95-169-10$ & $77.2 \mathrm{ab}$ & $97.8 \mathrm{ab}$ & $32.3 \mathrm{ab}$ & $30.2 \mathrm{a}-\mathrm{d}$ & $40.2 \mathrm{a}-\mathrm{c}$ & $4.0 \mathrm{c}$ \\
\hline $95-331-10$ & $87.3 \mathrm{~b}$ & $101.3 \mathrm{ab}$ & $25.0 \mathrm{a}$ & $35.0 \mathrm{a}-\mathrm{d}$ & $64.5 \mathrm{~d}$ & $1.0 \mathrm{a}$ \\
\hline Jennifer & $76.5 \mathrm{ab}$ & $100.8 \mathrm{ab}$ & $29.0 \mathrm{a}$ & $37.5 \mathrm{~d}$ & $41.8 \mathrm{a}-\mathrm{c}$ & $3.7 \mathrm{bc}$ \\
\hline $95-157-6$ & $90.0 \mathrm{~b}$ & $103.7 \mathrm{ab}$ & $23.3 \mathrm{a}$ & $35.3 \mathrm{~b}-\mathrm{d}$ & $39.7 \mathrm{a}-\mathrm{c}$ & $3.6 \mathrm{bc}$ \\
\hline $92-237-9$ & $79.6 \mathrm{~b}$ & $104.4 \mathrm{ab}$ & $30.6 \mathrm{ab}$ & $30.0 \mathrm{a}-\mathrm{c}$ & $39.8 \mathrm{a}-\mathrm{c}$ & $2.9 \mathrm{a}-\mathrm{c}$ \\
\hline Spotlight & $88.7 \mathrm{~b}$ & $102.0 \mathrm{ab}$ & $26.0 \mathrm{a}$ & $36.0 \mathrm{~b}-\mathrm{d}$ & $38.5 \mathrm{ab}$ & $3.9 \mathrm{c}$ \\
\hline $95-169-8$ & $68.7 \mathrm{ab}$ & $95.3 \mathrm{ab}$ & $39.7 \mathrm{ab}$ & $35.7 \mathrm{~b}-\mathrm{d}$ & $44.7 \mathrm{a}-\mathrm{c}$ & $4.4 \mathrm{c}$ \\
\hline $95-160-49$ & $93.8 \mathrm{~b}$ & $111.0 \mathrm{~b}$ & $17.7 \mathrm{a}$ & $35.0 \mathrm{a}-\mathrm{d}$ & $48.0 \mathrm{bc}$ & $2.8 \mathrm{a}-\mathrm{c}$ \\
\hline Helen & $73.0 \mathrm{ab}$ & $93.6 \mathrm{a}$ & $31.0 \mathrm{ab}$ & $37.4 \mathrm{~d}$ & $47.2 \mathrm{a}-\mathrm{c}$ & $3.3 \mathrm{bc}$ \\
\hline $\mathrm{MSE}^{\mathrm{x}}$ & 161.5 & 53.7 & 106.0 & 10.6 & 37.7 & 1.0 \\
\hline \multicolumn{7}{|c|}{ Source of variation (ANOVA) } \\
\hline Genotypes (G) & $* * *$ & $*$ & $*$ & $* * *$ & $* * *$ & $* * *$ \\
\hline Blocks (B) & NS & NS & NS & $*$ & NS & NS \\
\hline Cropping Systems (CS) & $* * *$ & $* * *$ & NS & NS & NS & NS \\
\hline $\mathrm{G} \times \mathrm{B}$ & NS & NS & NS & NS & NS & NS \\
\hline $\mathrm{G} \times \mathrm{CS}$ & NS & NS & NS & NS & NS & NS \\
\hline
\end{tabular}

zTukey's Honestly Significant Difference test at $P=0.05$.

yPlant uniformity index scale for flowering date, flower distribution, plant shape, consumer appeal was a $1-5$ scale, with $1=$ non-uniform, $5=$ uniform.

${ }^{x}$ Estimate of mean square error (MSE) used to calculate Tukey's honestly significant difference (5\% HSD) for mean separations. Means followed by different letter are significantly different from each other.

ws, ${ }^{*, * * * * * *}$ Nonsignificant or significant at $P \leq 0.05,0.01$, and 0.001 levels, respectively.

'Snowscape', a day-neutral semi-prostrate cultivar, was significantly earlier than all other cultivars for days to first flower (Table 2). Other cultivars were significantly later than 'Snowscape', including one non-prostrate ('Spotlight') and many other prostrates (90275-27, 95-105-2, 95-331-6, 95-331-10, 95157-6, 92-237-9, 95-160-49). The remaining cultivars overlapped with 'Snowscape' and the latter group. In contrast, most prostrate genotypes and commercial cultivars were not significantly different for days to $100 \%$ flowering, based on mean separations (Table 2 ); only 'Helen' was significantly earlier and 95-160-49 was significantly later. Thus, most prostrate genotypes flowered as early as commercial, non-prostrate cultivars.

Flowering duration was significantly shorter for 90-275-27, 95-105-2, 95-331-6, 95-331-10, 'Jennifer', 95-157-6, 92-2379, 'Spotlight', and 95-160-49 than for the remaining cultivars (Table 2). 'Snowscape' had the longest flowering duration of $53 \mathrm{~d}$, probably due to day neutrality. Many prostrate cultivars did not flower for as long a period as is desirable.

The tallest plants (height) were primarily the commercial cultivars, particularly 'Helen' and 'Jennifer'. Genotype 90-275-27 had the shortest height, which was significantly different than all other cultivars (Table 2). Clearly, prostrate types vary for the relative degree of "prostrate" growth.

The greatest plant width, which was significantly greater than all other cultivars, occurred with 95-331-10 and 95-331-6 (Table 2). The remaining prostrate and non-prostrate cultivars overlapped considerably. A greater dimension (width) can be achieved with some prostrates in comparison with standard cushion cultivars. In the case of 95-331-10 (64.5 cm) and 95-331-6 $(53.2 \mathrm{~cm})$ the width dimensions were large enough to be problematic for sleeving and shipping. The best choices for proper plant width (in pots) of prostrate plants, similar to commercial non-prostrate cultivars, would be 95-169-8, 92-237-9, 95-157-6, 95-169-10, 90 275-27, and 'Snowscape'.

Two prostrate (95-169-10, 95-169-8) and two commercial ('Debonair', 'Spotlight') cultivars were significantly more uniform than all other genotypes (Table 2). Most other prostrate cultivars overlapped or were significantly different for plant uniformity. The least uniform prostrate was 95-331-10.

The index of traits, a summation (into one value or score) of all traits evaluated in the production trial, showed significant differences between cultivars and highly significant differences between the cropping systems (Table 3 ). Blocks (replications) and all interactions were nonsignificant. Values for individual pots ranged from -7.41 to +8.32 (data not shown), while genotypic means showed prostrate 95 160-49 with the lowest and most undesirable index value (-2.36), significantly worse than all other genotypes in the study (Table 3 ). 'Snowscape' had the highest index value $(+3.47)$, which was significantly higher than all other genotypes. All other genotypes ranked in between, but overlapped with 95-160-49 and 'Snowscape', and were not statistically different from each other (Table 3). Other genotypes with very high index scores included three prostrates: 95-331-6 (2.36), 95-169-10 (1.64), and 95-169-8 (2.46). With the excep-
Table 3. Mean separations (Tukey's 5\% $\mathrm{HSD}^{\mathrm{z}}$ ) and ANOVA for the index of traits (Gesick, 1997) of prostrate vs. non-prostrate garden chrysanthemums grown under two cropping systems.

\begin{tabular}{lrc}
\hline Cultivar & Mean index value & 5\% HSD \\
\hline $90-275-27$ & -0.66 & $\mathrm{ab}$ \\
$95-105-2$ & -1.25 & $\mathrm{ab}$ \\
Jessica & -0.32 & $\mathrm{ab}$ \\
$95-331-6$ & 2.36 & $\mathrm{ab}$ \\
Snowscape & 3.47 & $\mathrm{~b}$ \\
Debonair & -0.29 & $\mathrm{ab}$ \\
$95-169-10$ & 1.64 & $\mathrm{ab}$ \\
$95-331-10$ & -0.46 & $\mathrm{ab}$ \\
Jennifer & -0.54 & $\mathrm{ab}$ \\
$95-157-6$ & -1.66 & $\mathrm{ab}$ \\
$92-237-9$ & 0.20 & $\mathrm{ab}$ \\
Spotlight & -1.26 & $\mathrm{ab}$ \\
$95-169-8$ & 2.46 & $\mathrm{ab}$ \\
$95-160-49$ & -2.36 & $\mathrm{a}$ \\
Helen & 0.48 & $\mathrm{ab}$ \\
MSE & 5.71 & \\
Source of variation (ANOVA) & \\
\hline Genotypes (G) & $*$ & \\
Blocks (B) & NS & \\
Cropping systems (CS) & $* * *$ & \\
G $\times$ B & NS & NS \\
G $\times$ CS & C & \\
\hline
\end{tabular}

'Tukey's Honestly Significant Difference test at $P \leq 0.05$.

yThe index of traits was calculated by first standardizing data to $\mathrm{z}$-scores, prior to summing the $\mathrm{z}$-scores using the following equation: Index of Traits Number $=[-$ plant height + plant uniformity - flowering earliness (or days to first flower) + flowering duration - days to $100 \%$ flowering].

${ }^{x}$ Estimate of mean square error (MSE) used to calculate Tukey's honestly significant difference (5\% HSD) for mean separations. Means followed by different letter are significantly different from each other. ns, *, *** Nonsignificant or significant at $P \leq 0.05$ and 0.001 , respectively.

tion of 'Helen', Yoder cultivars had negative index values although none were significantly different from each other.

In the consumer evaluations, participants consistently ranked the commercial, non-prostrate cultivars higher than the prostrate genotypes for flower color, flower form, quality, and overall appearance (Table 4). The only exception was 92-237-9 being ranked higher than 'Spotlight' for flower form, although these two rankings were not statistically significantly different from each other. Comments from the evaluators revealed that most preferred decoratives (non-prostrate cultivars, 'Snowscape', 92-237-9) to daisies (the remaining prostrate genotypes).

\section{Discussion}

Yoder's Regular vs. Fast Cropping systems differed significantly for days to first and $100 \%$ flowering, as would be expected since the planting dates differed (Table 2). However, flowering duration was not significantly different. Thus, containers from both cropping systems remained in flower for the same duration prior to a killing freeze during 1999.

Genotypes (cultivars) differed significantly for days to first and $100 \%$ flowering, flowering duration, plant height, plant width, and plant uniformity (Table 2). Flowering 
Table 4. Mean rankings using Friedman's Rank Test and mean separations (5\% LSD), for consumer evaluations of select prostrate and non-prostrate chrysanthemums (unpinched) from flower color classes (yellow, lavender, bronze, white, red) for flower color, flower form, quality, and overall appearance.

\begin{tabular}{|c|c|c|c|c|c|}
\hline $\begin{array}{l}\text { Color } \\
\text { class }\end{array}$ & Cultivar & $\begin{array}{l}\text { Flower } \\
\text { color }\end{array}$ & $\begin{array}{c}\text { Flower } \\
\text { form }\end{array}$ & Quality & $\begin{array}{c}\text { Overall } \\
\text { appearance }\end{array}$ \\
\hline Yellow & $\begin{array}{l}\text { Jessica } \\
95-105-2\end{array}$ & $\begin{array}{l}7.2 \mathrm{ab}^{\mathrm{z}} \\
3.7 \mathrm{f}\end{array}$ & $\begin{array}{l}6.2 \mathrm{c}^{\mathrm{y}} \\
2.9 \mathrm{f}\end{array}$ & $\begin{array}{l}6.7 \mathrm{~b}^{\mathrm{x}} \\
4.0 \mathrm{fg}\end{array}$ & $\begin{array}{l}7.2 \mathrm{a}^{\mathrm{w}} \\
2.8 \mathrm{e}\end{array}$ \\
\hline Pink & Debonair & $6.7 \mathrm{~b}$ & $7.1 \mathrm{a}$ & $5.9 \mathrm{c}$ & $6.4 \mathrm{~b}$ \\
\hline Lavender & Snowscape & $5.2 \mathrm{~d}$ & $6.3 \mathrm{bc}$ & $5.1 \mathrm{e}$ & $5.2 \mathrm{c}$ \\
\hline Bronze & $\begin{array}{l}\text { Jennifer } \\
95-169-10\end{array}$ & $\begin{array}{l}5.3 \mathrm{~d} \\
4.0 \mathrm{ef}\end{array}$ & $\begin{array}{l}4.9 \mathrm{~d} \\
4.4 \mathrm{~d}\end{array}$ & $\begin{array}{l}5.9 \mathrm{~cd} \\
5.2 \mathrm{de}\end{array}$ & $\begin{array}{l}5.3 \mathrm{c} \\
4.4 \mathrm{~d}\end{array}$ \\
\hline White & $\begin{array}{l}\text { Spotlight } \\
92-237-9\end{array}$ & $\begin{array}{l}6.0 \mathrm{c} \\
5.6 \mathrm{~cd}\end{array}$ & $\begin{array}{l}6.6 \mathrm{a}-\mathrm{c} \\
6.9 \mathrm{ab}\end{array}$ & $\begin{array}{l}7.4 \mathrm{a} \\
3.8 \mathrm{~g}\end{array}$ & $\begin{array}{l}7.3 \mathrm{a} \\
4.3 \mathrm{~d}\end{array}$ \\
\hline Red & $\begin{array}{l}\text { Helen } \\
95-169-8\end{array}$ & $\begin{array}{l}7.3 \mathrm{a} \\
4.0 \mathrm{e}\end{array}$ & $\begin{array}{l}6.0 \mathrm{c} \\
3.7 \mathrm{e}\end{array}$ & $\begin{array}{l}6.7 \mathrm{~b} \\
4.4 \mathrm{f}\end{array}$ & $\begin{array}{l}7.6 \mathrm{a} \\
4.5 \mathrm{~d}\end{array}$ \\
\hline
\end{tabular}

${ }^{25} \%$ Least Significant Difference (LSD) test at alpha $=0.5$. LSD $=0.62$. Means followed by different letter are significantly different from each other. ${ }^{\mathrm{y}} \mathrm{LSD}=0.58$.

${ }^{\mathrm{x}} \mathrm{LSD}=0.61$.

${ }^{\mathrm{w}} \mathrm{LSD}=0.69$

date differences are not unexpected since the 15 genotypes were from different short day flowering response groups (N. Anderson, unpublished data; Yoder Brothers, 1999). Most prostrate genotypes flowered as early as the commercial comparisons (Table 2), indicating that these prostrate genotypes were in similar short day response groups. 'Snowscape', a semi-prostrate day-neutral cultivar, was earlier than all other genotypes for days to first flower and had the longest flowering duration. While flowering earliness can be attributed to a decreased short day response group, the significantly greater flowering duration is due to day neutrality (Anderson, 1991). Previous research has documented the existence of day neutral genotypes, particularly 83-267-3, P.P. No. 6,884 (Anderson, et al., 1988; Anderson and Ascher, 2001). Since 'Snowscape' is semi-prostrate it would be the best genetic source for creating early, continual flowering prostrate cultivars.

Genotypic differences in plant height were also found (Table 2), due to the use of prostrate and commercial cushion cultivars. Since prostrates have different height : width ratios than the standard comparisons, this finding is not unexpected. Genotype 90-275-27 was significantly shorter (prostrate) than all other genotypes and would be the best genetic source for compact prostrates. The effect of the container rims on artificially increasing plant height of the prostrate genotypes is a distinct possibility. In the prostrate genotypes, horizontally growing stems or non-rooting stolons reaching the container rims (with a 1 " headspace) were forced primarily in an upward direction. Once the vertically growing stems surpassed the container rim, it was observed that it took a variable number of nodes before the stems resumed horizontal growth. In cases where the stolons were forced underground, they did not root or become rhizomes. Rhizome production is essential for winter survival, but occurs only after flowering (Anderson and Gesick, 2003). Field data for genotype 90-275-27, documented that first-and second-year-old clones achieved a height of 7.5 and $15.25 \mathrm{~cm}$, respectively (An- derson, unpublished data, 1999). In contrast, 90-275-27 grew to an average height of 27.8 $\mathrm{cm}$ in the current production study, more than $2 \times$ the height of second-year plants. This is in contrast with the Chinese groundcover or "creeping" chrysanthemums, which reach a greater height $(20-30 \mathrm{~cm})$ in first year, fieldgrown plants (Junyu, et al., 1995). Further research needs to be performed to determine whether this occurs in all container-grown prostrate genotypes and whether the plants produce rhizomes as well as stolons.

'Snowscape', 95-169-8, 92-237-9, 95-1576, 95-169-10, and 90-275-27 had the most acceptable plant width for shipping (Table 2 ); mean separations overlapped with most of the Yoder cushion cultivars. Significantly greater widths of the full-sibs 95-331-10 and 95-331-6 indicate that these genotypes could produce greater plant diameters when not grown in containers. However, for container production and consumer sales, such prostrates would need plant growth regulator application(s) to prevent damage during the sleeving and shipping phases. It would be more cost effective, however, if the breeding program selected against increased widths in container-grown plants.

Differences in plant uniformity between the prostrate genotypes were unexpected, since all were clonally propagated. Full-sibs 95-169-8 and 95-169-10 had the same plant uniformity as 'Debonair' and 'Spotlight', all of which were significantly more uniform than the remaining Yoder or prostrate genotypes (Table 2). The least uniform prostrate genotype was 95-33110 , significantly different from all others.

'Snowscape' had the highest (best) index of traits ranking and was significantly better than all other genotypes (Table 3). This was unexpected, since the commercial Yoder cultivars are selected for superior performance in mum pan production (Langevin, 1992). Other prostrates with high index of trait scores included 95-331-6, and the full-sibs 95-169-8 and 95-169-10. Prostrate 95-160-49 ranked the lowest of all genotypes.

Consumer evaluations of flower color, flower form, quality, and overall appearance were highest for the non-prostrate cultivars (Table 4). 'Snowscape' and 'Jennifer' had statistically similar ratings for flower color and overall appearance, although their scores were near the base of the rating scales. It is not known whether the other genotypes not selected for the consumer evaluations would have shown similar trends. While consumers prefer decorative flower forms over daisies, as their respective nationwide market shares indicate ( $76 \%$ vs. $22 \%$, respectively), several prostrates without fully-double decorative flower forms ranked the same as their comparisons. For instance, 'Jennifer' and 95-169-10 were not statistically different (Table 4). However, 'Snowscape', a decorative, was significantly different from its comparison, 'Debonair'. This may be attributable to day neutrality creating 'Snowscape' with earlier flowering and flower quality of the earliest-to-flower blooms being past their prime at the time of the consumer evaluations.

Further production trials are necessary to create the highest quality prostrate chrysanthemum phenotype that would be acceptable and highly desirable to consumers. It was not obvious to the consumers participating in the evaluations that any of the plants were prostrate and could be planted in the landscape as groundcovers. Thus, mum pans may be less desirable than hanging baskets or larger diameter color pots to enhance the prostrate phenotype for the consumer at the time of purchase and make a connection with its novel use in the landscape. As in the case of Wave ${ }^{\mathrm{TM}}$ petunias, grower, retailer, landscape designer, and consumer training in the landscape was necessary for the first prostrate petunia ('Purple Wave') (PanAmerican Seed Co., 1997; Rice, 1999).

Prostrate chrysanthemums may afford a unique opportunity to conduct basic research on the mechanism(s) by which a single genotype can produce non-rooting stolons and rhizomes. Few other dicotyledons, if any, have both rhizomes and stolon-like structures; most are monocotyledons, e.g., Cynodon dactylon, Digitaria milanjiana (Hacker, 1983; Miller and Dickens, 1996). It has not been documented whether the Chinese groundcover chrysanthemums also possess non-rooting stolons and rhizomes (Junyu et al., 1995), nor whether their "creeping" habit matches the genotypes in the current study. An understanding of these phenomena may allow for gene characterization and genetic transformation of other crops.

Future breeding efforts should include specific prostrate parents identified in this study to be significantly better than the comparisons. The two best genotypes were 'Snowscape' and 90-275-27 (Patent Pending). 'Snowscape' possessed the earliest flowering, the longest flowering duration (due to day neutrality), an acceptable plant width, and the highest index of traits score. Genotype 90-275-27 had the shortest height and acceptable plant width. However, since both genotypes are decoratives (full-double flower forms) they cannot be crossed with each other since they possess $100 \%$ gynoecious florets. Each could be used as a female parent with either full-sib 
95-169-8 or 95-169-10 (as males), both of which were the most uniform prostrates. In subsequent generations, it may be possible to select genotypes that are early flowering with the longest flowering duration, short stature in container and field trials, acceptable plant widths, superior uniformity, and the highest index of traits. The heritability of the prostrate plant form also needs to be determined via classical breeding; gene action may also differ between parents from differing pedigrees and interspecific crosses.

\section{Literature Cited}

Alfors, J.T. 1977. Growing cascades in Davis, California. The chrysanthemum, J. Natl. Chrysanthemum Soc. 33(3):108-109.

Anderson, N.O. 1991. The discovery of day-neutral chrysanthemums. Greenhouse Grower 9: $50-53$.

Anderson, N.O. and P.D. Ascher. 2001. Selection of day-neutral, heat-delay-insensitive Dendranthema $\times$ grandiflora genotypes. JASHS 126(6): 710-721.

Anderson, N.O.,P.D. Ascher, and R.E. Widmer. 1988. Chrysanthemum plant-Day neutral: Mn. Sel. 83-267-3. U.S. Plant Patent 6,884.

Anderson, N.O. and E. Gesick. 2003. Phenotypic markers for selection of winter hardy garden chrysanthemum (Dendranthema xgrandiflora Tzvelv.) genotypes. Scientia Hort. (In press.)

Bruckhaus, G. 1975. Growing cascades in the northeast. The Chrysanthemum, J. Natl. Chrysanthemum Soc. 31(2):87-88.

Butterfield, H.M. n.d. Chrysanthemum culture in California. Univ. of California, College of Agr.
Agr. Expt. Stn. and Ext. Serv., Manual 4.

Carpenter, W.J. and T.B. Shackelford. 1966. Garden chrysanthemum in Kansas. Dept. of Hort., Kansas Agr. Expt. Stn., Manhattan, Kans. Bul. No. 485 .

Clark, R.B. 1962. History of culture of hardy chrysanthemums. Natl. Chrysanthemum Soc. Bul. 18(3):144.

Dowrick, G.J. 1953. The chromosomes of chrysanthemums, II: Garden varieties. Heredity 7(1):59-72.

Gesick, E. 1997. Development of selection criteria for prostrate chrysanthemums used as outdoor pot mums. MS Thesis, Univ. of Minnesota.

Hacker, J.B. 1983. Inheritance of stolon development, rhizome development and setigerous lemmas in the Digitaria milanjiana complex, and its taxonomic significance. Aust. J. Bot. 31:357-369.

Harris, J.G. and M.W. Harris. 1994. Plant identification terminology: An illustrated glossary. Spring Lake Publ., Spring Lake, Utah.

Junyu, C., W. Siqing, W. Xiangchun, and W. Pengwei. 1995. Thirty years' studies on breeding ground-cover chrysanthemum new cultivars. Acta Hort. 404:30-36.

Langevin, D. 1992. The growing and marketing of fall mums. Annedawn Publ., Norton, Mass.

Longley, L.E. 1936. New chrysanthemums named. Minnesota Hort. 64(2):26.

Longley,L.E. 1938. Thousands of "Mums" displayed at U. Farm. Minnesota Hort. 66(9):174.

Longley, L.E. 1943. Garden chrysanthemums for Minnesota. Minnesota Hort. 71:76-77.

Longley, L.E. 1949. Chrysanthemums for the north. Horticulture 27(11):404.

Longley, L.E. 1950. Chrysanthemum breeding at the University of Minnesota. Natl. Chrysanthemum
Soc. Bul. 6:45-46.

Miller, G. 1976. Growing cascades in the southwest. The Chrysanthemum, J. Natl. Chrysanthemum Soc. 32(4):188-189.

Miller, G.L. and R. Dickens. 1996. Bermudagrass carbohydrate levels as influenced by potassium fertilization and culitvar. Crop Sci. 36: 1283-1289.

Montgomery, D.C. 1991. Design and analysis of experiments. 3rd ed. Wiley, New York.

Morrison, B.Y. 1923. Chrysanthemums for the home. USDA. Farmer's Bul. No. 1311.

PanAmerican Seed Company. 1997. Welcome to the Wave Rave. http://www.wave-rave.com/ index.cfm

Rice, G. 1999. Discovering annuals. Timber Press, Portland, Ore.

Smith, E.D. and A. Laurie. 1928. Chrysanthemum breeding. Michigan State Coll. of Agr. and Appl. Sci., Agr. Expt. Stn., Spec. Bul. No. 186.

Teynor, T.M. 1990. Selection for earlier flowering dates in chrysanthemums (Dendranthema grandiflora Tzvelv). PhD Diss., Univ. of Minnesota, St. Paul.

U.S. Dept. of Agriculture Statistics Board. 1995. Floriculture crops 1994 summary. http: /usda.mannlib.cornell.edu/reports/nassr/other/ zfc-bb/flor0495.txt

U.S. Dept. of Agriculture Statistics Board. 2002. Floriculture crops 2001 summary. http: /usda.mannlib.cornell.edu/reports/nassr/other/ zfc-bb/flor0401.txt

Widmer, R.E. 1978. Chrysanthemum named 'Minngopher'. U.S. Plant Patent No. 4,327. Washington, D.C. http://patft.uspto.gov/

Yoder Brothers, Inc. 1999. Pot mums, cut mums, and garden mum catalogs. Yoder Brothers, Inc., Barberton, Ohio. 